\title{
Localities of three rare mammal species in central and northeastern Poland
}

\author{
Grzegorz LESIŃsKI* and Jakub GRYZ** \\ *Department of Functional Food and Commodity, Warsaw University of Life Sciences - SGGW, \\ Nowoursynowska159 C,02-787 Warsaw,Poland; e-mail: glesinski@wp.pl \\ **Division of Forest Zoology and Wildlife Management, Warsaw University of Life Sciences - SGGW. \\ Nowoursynowska159 C,02-776Warsaw,Poland; e-mail:Jakub.Gryz@wl.sggw.waw.pl
}

\begin{abstract}
Analyses of 69 collections of the tawny owls' pellets ( 28 containing over 100 prey items) revealed the presence of three rare mammal species on several localities in central and northeastern Poland: Muscardinus avellanarius (11 localities), Sicista betulina (3), and Crocidura lencodon (2). The obtained results supplemented data on their distribution close to the borders of continuous ranges. The Kampinos Forest was confirmed as important refuge of $M$. avellanarius, and the lower basin of the Biebrza Valley for both $M$. avellanarius and S. betulina.
\end{abstract}

Key words: Crocidura leucodon, Muscardinus avellanarius, Sicista betulina, distribution, tawny owl's pellets, Mazovia, Podlasie

\section{INTRODUCTION}

Studies of owls' diet give an information about the distribution of many species of small mammals (Pucek \& Raczyński 1983). In central and northeastern Poland some species attain borders of their continuous range, including: northern birch mouse Sicista betulina (Pallas, 1778), common dormouse Muscardinus avellanarius (Linnaeus, 1758), and bicoloured whitetoothed shrew Crocidura leucodon (Hermann, 1780). As the specific faunistic studies focused on their distribution in this part of Poland were not conducted, many localities have been discovered during other studies.

For the three mentioned species the Mazovia is a region where the limits of their ranges occur: the south-western or north-western (S. betulina, M. avellanarius - Pucek 1983a, b), and the northern (C. leucodon - Pucek \& Michalak 1983). They reach the vicinity of the Warsaw city: S. betulina was recorded near its eastern borders (Lesiński et al. 1998), M. avellanarius slightly exceeds the city from the western side (Pucek 1983b), and C. leucodon was reported from the city at one isolated site (Luniak \& Nowicki 1990). In the countries bordering on the north-eastern Poland, $M$. avellanarius and $S$. betulina are relatively common, while $C$. leucodon occurs only in Belarus (Krapp 1999, Morris 1999, Pucek 1999, Grišanov \& Beljakov 2000). The presence of these species were often confirmed based on analyses of owl pellets (Dzjamjančyk 1988, Tišečkin 1997, Balčiauskienè 2005, Balčiauskienė et al. 2005).

The aim of this paper is to supplement data on the distribution of the above mentioned species of small mammals using the material of bone remains from the tawny owl's food.

\section{MATERIAL AND METHODS}

Study area mostly covered the Mazovia and Podlasie regions, and included a part of the Mazurian Lake District (central and north-eastern Poland, ca. $60,000 \mathrm{~km}^{2}$ ). Tawny owl's pellets were collected from 1980 to 2007 at 69 sites, mostly (47) situated on the Mazovian Low- 
land. Samples' collection was not specially aimed at finding the three analysed species, and took place in various habitats and regions. Samples with the presence of analysed species (14), and additionally those containing more than 100 vertebrate prey items (21), were taken into consideration. For each site the name and geographical coordinates were given. Species identification based on the skull characteristics presented by Pucek (1984). A bone material is usually damaged by tawny owls, and in some cases only mandibles were found.

\section{RESULTS}

\section{Distribution of localities}

The presence of the mammal species under study was confirmed on the following localities (geographical coordinates, date of pellets' collection and number of individuals of each species were given - Fig. 1):

1. Bialy Grąd (Kampinos National Park), 52 $20^{\circ} \mathrm{N}, 20^{\circ} 48^{\prime} \mathrm{E}: 12.05 .1983-1$ M. avellanarius

2. Bobrowa near Bialystok, $53^{\circ} 06^{\prime} \mathrm{N}, 23^{\circ} 21^{\prime} \mathrm{E}$ : 07.08.2007 - 4 S. betulina

3. Brzeźce, $51^{\circ} 39^{\prime} \mathrm{N}, 21^{\circ} 00^{\prime} \mathrm{E}: 18.07 .2006-1 \mathrm{M}$. avellanarius

4. „Dęby Napiwodzkie” reserve, $53^{\circ} 31^{\prime} \mathrm{N}, 20^{\circ} 41^{\prime} \mathrm{E}: 22.05 .2007-3$ S. betulina

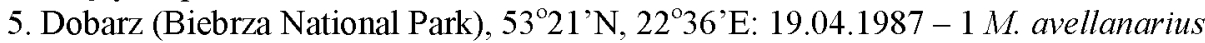

6. Dziekanów Leśny (Kampinos National Park), 52 20’ N, 20 50’'E: 20.06.2000-1 M. avellanarius

7. Krzywa Góra (Kampinos National Park), 52²0’N, 20²5’E: 12.10 .1995 - 1 M. avellanarius

8. Natolin near Nur, 52 $38^{\prime} \mathrm{N}, 2^{\circ} 18^{\prime} \mathrm{E}$ : $28.07 .2002-1$ C. leucodon, 1 M. avellanarius; $31.05 .2003-2$ C. leucodon, 4 M. avellanarius; $03.07 .2003-1 \mathrm{M}$. avellanarius; 30.04 .2005 $-1 \mathrm{M}$. avellanarius; 17.06.2006 - $2 \mathrm{M}$. avellanarius; 08.06.2007 - $2 \mathrm{M}$ avellanarius; 17.08.2007-1 M. avellanarius; 22.09.2007-1M. avellanarius

9. Noski near Ceranów, 52³9’ $\mathrm{N}, 2^{\circ}{ }^{\circ} 12^{\prime} \mathrm{E}$ : 25.09.1999-1 M. avellanarius

10. Olszowa Droga (Biebrza National Park), $53^{\circ} 25^{\prime} \mathrm{N}, 22^{\circ} 35^{\prime} \mathrm{E}$ : 01.05.2005 - $2 \mathrm{M}$. avellanarius; $01.072005-1$ M. avellanarius, 6 S. betulina; 24.06.2006 - 4 S. betulina; 09.07.2006 - 2 M. avellanarius, 6 S. betulina; $29.07 .2006-2$ M. avellanarius, 2 S. betulina; 08.06.2007-3 M. avellanarius, 9 S. betulina; 14.07.2007-2 S. betulina

11. Ponurzyca (Mazowiecki Landscape Park), 52 ${ }^{\circ} 00^{\prime} \mathrm{N}, 21^{\circ} 24^{\prime} \mathrm{E}$ : 17.02 .2002 Ponurzyca $3 M$ avellanarius; $26.06 .2002-2 M$. avellanarius

12. Seroczyn, 52 34 'N, 22 21'E: 08.07.1994 - 1 C. leucodon; 03.07.1996 - 5 C. leucodon; 03.07.1999-1 C. leucodon

13. Sowia Wola Folwarczna (Kampinos National Park), 52²1'N, 20³7'E: 09.09.2004 $3 \mathrm{M}$. avellanarius; 30.05 .2005 - $19 \mathrm{M}$. avellanarius; 10.10 .2005 - $5 \mathrm{M}$. avellanarius; $01.10 .2006-8 \mathrm{M}$. avellanarius

14. Zamczysko (Kampinos National Park), 52 $18^{\prime}$ N, 20 $30^{\prime} \mathrm{E}$ : $04.2003-2$ M. avellanarius; $11.2004-1$ M. avellanarius; $27.10 .2006-2$ M. avellanarius

M. avellanarius was recorded on 11 localities, S. betulina on 3 localities, and C. leucodon on 2 localities (Fig. 1). The samples with more than 100 prey items, in which the three species were absent (sample size in brackets):

15. Białowieża park, $52^{\circ} 42^{\prime} \mathrm{N}, 23^{\circ} 50^{\prime} \mathrm{E}(246)$

16. Buchnik Forest, $52^{\circ} 21^{\prime} \mathrm{N}, 20^{\circ} 55^{\prime} \mathrm{E}$ (305)

17. Jegiel, $52^{\circ} 35^{\prime} \mathrm{N}, 21^{\circ} 37^{\prime} \mathrm{E}$ (109)

18. Klembów “Dębina I" reserve, $52^{\circ} 24^{\prime} \mathrm{N}, 21^{\circ} 22^{\prime} \mathrm{E}$ (368)

19. Konstancin-Jeziorna, $52^{\circ} 03^{\prime} \mathrm{N}, 21^{\circ} 06^{\prime} \mathrm{E}$ (145) 
20. Lipków, 52 ${ }^{\circ} 16^{\prime} \mathrm{N}, 20^{\circ} 48^{\prime}$ E (229)

21. Pniewo Wielkie, $52^{\circ} 56^{\prime} \mathrm{N}, 20^{\circ} 29^{\prime} \mathrm{E}$ (808)

22. Rogów, $51^{\circ} 49^{\prime} \mathrm{N}, 19^{\circ} 54^{\prime} \mathrm{E}$ (691)

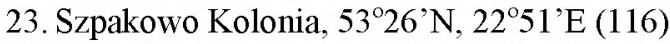

24. Szymaki, $53^{\circ} 26^{\prime} \mathrm{N}, 23^{\circ} 41^{\prime} \mathrm{E}$ (124)

25. Trzyrzeczki Forest, $53^{\circ} 41^{\prime} \mathrm{N}, 23^{\circ} 12^{\prime} \mathrm{E}$ (905)

26. Tustań, $52^{\circ} 30^{\prime} \mathrm{N}, 20^{\circ} 22^{\prime} \mathrm{E}$ (458)

27. Warsaw, Arkadia Park, $52^{\circ} 11^{\prime} \mathrm{N}, 21^{\circ} 01^{\prime} \mathrm{E}$ (186)

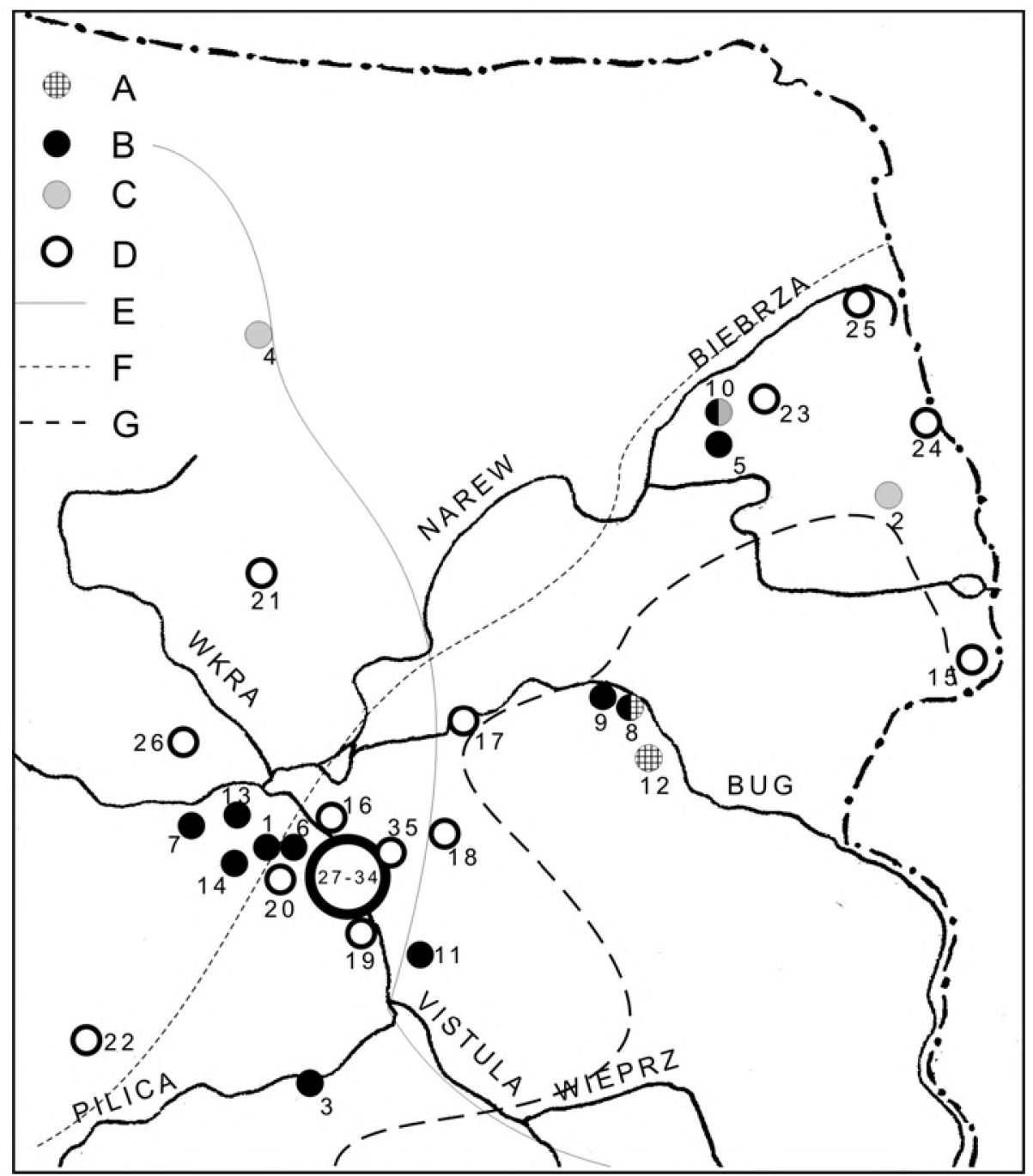

Fig. 1. Distribution of localities of the three analysed species and sites without them in central and northeastern Poland (numbered as in the text). Previously known geographic ranges of the three species (after Pucek 1984), as well as main rivers and the borders of Poland, are shown; A - Crocidura leucodon, B - Muscardinus avellanarius, C - Sicista betulina, D - sites without these 3 species; Limits of ranges: E - Sicista betulina (south-western), F - Muscardinus avellanarius (north-western), G-Crocidura leucodon (northern) 
28. Warsaw, Bielany Park, $52^{\circ} 17^{\prime} \mathrm{N}, 20^{\circ} 57^{\prime} \mathrm{E}$ (262)

29. Warsaw, Kabacki Forest, $52^{\circ} 07^{\prime} \mathrm{N}, 21^{\circ} 03^{\prime} \mathrm{E}$ (386)

30. Warsaw, Łazienki Park, $52^{\circ} 12^{\prime} \mathrm{N}, 21^{\circ} 01^{\prime} \mathrm{E}$ (315)

31. Warsaw, Mlociny Park, $52^{\circ} 18^{\prime} \mathrm{N}, 20^{\circ} 55^{\prime} \mathrm{E}$ (267)

32. Warsaw, Natolin Forest, $52^{\circ} 08^{\prime} \mathrm{N}, 21^{\circ} 04^{\prime} \mathrm{E}$ (173)

33. Warsaw, Sobieski Forest, $52^{\circ} 13^{\prime} \mathrm{N}, 21^{\circ} 09^{\prime} \mathrm{E}$ (281)

34. Warsaw, Wilanów Park, 52 $09^{\circ} \mathrm{N}, 21^{\circ} 05^{\prime} \mathrm{E}$ (384)

35. Zielonka, $52^{\circ} 17^{\prime} \mathrm{N}, 21^{\circ} 10^{\prime} \mathrm{E}(1073)$.

\section{Percent of the vertebrate prey}

Among localities of $M$. avellanarius, relatively high percent of this species in the vertebrate prey was noted in the Biebrza and Kampinos National Parks and forests near Nur (3.3-3.9\%). At one site the share of $S$. betulina was near $10 \%$. Remarkable is also the presence of four individuals of the latter species in a small sample from Bobrowa. C. leucodon belongs to the least frequently caught by tawny owls in the study area with a relatively low proportion to other prey items (Table 1).

Table 1. The share of three mammal species among vertebrate prey in the tawny owl's diet at the study sites; for small samples ( $<40$ ind.) the percent was not calculated.

\begin{tabular}{|c|c|c|c|c|c|c|c|}
\hline \multirow{2}{*}{ Locality } & \multirow{2}{*}{$\begin{array}{l}\text { Vertebrates } \\
\text { total }\end{array}$} & \multicolumn{2}{|c|}{$\begin{array}{l}\text { Muscardinus } \\
\text { avellanarius }\end{array}$} & \multicolumn{2}{|c|}{ Sicista betulina } & \multicolumn{2}{|c|}{$\begin{array}{l}\text { Crocidura } \\
\text { leucodon }\end{array}$} \\
\hline & & $\mathrm{N}$ & $\%$ & $\mathrm{~N}$ & $\%$ & $\mathrm{~N}$ & $\%$ \\
\hline $\begin{array}{l}\text { 1. Bialy Grąd } \\
\text { (Kampinos National Park) }\end{array}$ & 15 & 1 & - & 0 & 0 & 0 & 0 \\
\hline 2. Bobrowa near Białystok & 15 & 0 & 0 & 4 & - & 0 & 0 \\
\hline 3. Brzeźce & 68 & 1 & 1.5 & 0 & 0 & 0 & 0 \\
\hline 4. „Dęby Napiwodzkie” reserve & 41 & 0 & 0 & 3 & 7.3 & 0 & 0 \\
\hline 5. Dobarz (Biebrza National Park) & 61 & 1 & 1.6 & 0 & 0 & 0 & 0 \\
\hline $\begin{array}{l}\text { 6. Dziekanów Leśny } \\
\text { (Kampinos National Park) }\end{array}$ & 281 & 1 & 0.4 & 0 & 0 & 0 & 0 \\
\hline $\begin{array}{l}\text { 7. Krzywa Góra } \\
\text { (Kampinos National Park) }\end{array}$ & 47 & 1 & 2.1 & 0 & 0 & 0 & 0 \\
\hline 8. Natolin near Nur & 491 & 18 & 3.7 & 0 & 0 & 3 & 0.6 \\
\hline 9. Noski near Nur & 8 & 1 & - & 0 & 0 & 0 & 0 \\
\hline $\begin{array}{l}\text { 10. Olszowa Droga } \\
\text { (Biebrza National Park) }\end{array}$ & 300 & 10 & 3.3 & 29 & 9.7 & 0 & 0 \\
\hline $\begin{array}{l}\text { 11. Ponurzyca } \\
\text { (Mazowsze Landscape Park) }\end{array}$ & 268 & 5 & 1.9 & 0 & 0 & 0 & 0 \\
\hline 12. Seroczyn & 610 & 0 & 0 & 0 & 0 & 7 & 1.1 \\
\hline $\begin{array}{l}\text { 13. Sowia Wola Folwarczna } \\
\text { (Kampinos National Park) }\end{array}$ & 903 & 35 & 3.9 & 0 & 0 & 0 & 0 \\
\hline $\begin{array}{l}\text { 14. Zamczysko } \\
\text { (Kampinos National Park) }\end{array}$ & 118 & 5 & 4.2 & 0 & 0 & 0 & 0 \\
\hline
\end{tabular}




\section{DISCUSSION}

The results of studies on the tawny owl's diet published to date revealed several localities of rare mammal species in the study area. Large samples from the Bialowieża Forest contained such species as: Sorex caecutiens, Neomys anomalus, Dryomys nitedula, Glis glis, S. betulina (Ruprecht \& Szwagrzak 1987, Jędrzejewski et al. 1994). M. avellanarius was discovered in the Kampinos Forest (Goszczyński et al. 1993), in the Romincka Forest (Żmihorski \& Osojca 2006), and S. betulina in the Pisz Forest (Kowalski 1961), near the Łuknajno Lake (Kowalski \& Lesiński 1988), close to the eastern borders of Warsaw (Lesiński et al. 1998), and in the Romincka Forest (Osojca \& Żmihorski 2004, Żmihorski \& Osojca 2006).

The material presented in this paper supplemented data on the distribution of $M$. avellanarius. The Kampinos and Biebrza National Parks were confirmed as important refuges of this species (Pucek 1983b, Raczyński et al. 1984, Andrzejewski 2003, Sterzyńska \& Lesiński 2004). Forests near Nur appeared to be a new locality, as well as Brzeźce and Ponurzyca. Localities from the western part of the Kampinos Forest slightly correct previously known limit of its range. The absence of this species in large samples collected on the Plonsk and Ciechanów Plains (Tustań, Pniewo Wlk.) suggests that these areas lie out of its range, and confirms earlier opinions (Pucek 1983b).

$M$. avellanarius is relatively easily captured by tawny owls. Its absence in a sample of 368 vertebrates from the Klembów "Dębina I" reserve, that is characterized by a presence of suitable habitats (tree stands dominated by Quercus robur and Carpinus betulus), could suggest that this forest area is too small and isolated from other localities. Remarkable is also the absence of $M$. avellanarius in parks of Warsaw and suburban forests (see also Goszczyński et al. 1993, Gryz et al. in press), which indicates its sensitivity to a high level of urbanization. However, in the regions with more abundant populations, it was recorded in the peripheral zone of a large city, e.g. in Vilnius (Baranauskas 2005). It seems probable that in central and eastern Mazovia this species prefers wet forests. Many of its localities were situated at sites with a presence of such habitats.

Two new localities of $S$. betulina (Olszowa Droga, Bobrowa) are situated inside a known range, and the third one on its limit, just a few kilometers from the previously discovered locality (the Czame Lake, $53^{\circ} 32^{\prime} \mathrm{N}, 20^{\circ} 38^{\prime} \mathrm{E}$ - Pucek 1983a). The lack of this species in many samples from the Kampinos National Park indicates that this wooded area, rich in wetlands, lies out of its range. In the vicinity of Warsaw it probably does not exceed the Vistula river, though the closest locality is known only $10 \mathrm{~km}$ apart (Lesiński at al. 1998).

C. leucodon is a synanthropic species connected with the vicinity of human settlements (Krapp 1999), and consequently rarely caught by a tawny owl. Only some individuals of this owl living in habitats situated out of forests have an opportunity to find that prey. The range of C. leucodon mostly covers the eastern part of the Mazovia (Pucek 1983b), which reflects its presence in the material under study only from that area. The occurrence of this species in Warsaw (Luniak \& Nowicki 1990) was not confirmed in many large samples of the tawny owl's prey from that area (sites 27-34, Fig. 1), which could suggest even extinction of that probably small and isolating population.

\section{ACKNOWLEDGMENTS}

The authors would like to thank many colleagues for their help in collecting owl pellets, especially: Marek Blicharski, Grzegorz Blachowski, Marcin Dziedzic, Marek Kowalski, Dagny Krauze, Waldemar Merecz, Piotr Michalak, Ireneusz Mirowski, Bogumila Olech, Adam Olszewski, Pawel Pawlikowski, Bartłomiej Popczyk, Marcin Siuchno, Przemyslaw Stolarz, Izabela and Slawomir Śliwińscy, Marcin Tylutki, Błażej Wojtowicz. Bartłomiej Popczyk helped us to draw a figure. 


\section{REFERENCES}

ANDRZEJEWSKI R. 2003. Drobne ssaki owadożerne i gryzonie. In: ANDRZEJEWSKI R. (ed.), Kampinoski Park Narodowy. I. pp. 655-663. Kampinoski Park Narodowy, Izabelin, 728 pp.

BALČIAUSKIENE L. 2005. Analysis of Tawny Owl (Strix aluco) food remains as a tool for long-term monitoring of small mammals. Acta Zoologica Lituanica 15: 85-89.

BALČIAUSKIENE L., JUŠKAITIS R. \& ATKOČAITIS O. 2005. The diet of the Tawny Owl (Strix aluco) in south-western Lithuania during the breeding period. Acta Zoologica Lituanica 15: 13-20.

BARANAUSKAS K., BALČIAUSKAS L. \& MAZ̆EIKYTĖ R. 2005. Vilnius city theriofauna. Acta Zoologica Lituanica 15: $228-238$.

DZJAMJANČYK V. T. 1988. Charčovy spektr zvyčajnaj njajasyci (Strix aluco L.) u Belarusi. Vesci AN BSSR, Seryja bijalagicnyh nauk, 4: 86-91.

GOSZCZYŃSKI J., JABEOŃSKI P., LESחNSKI G. \& ROMANOWSKI J. 1993. Variation in diet of Tawny Owl Strix aluco L. along an urbanization gradient. Acta Ornithologica 27: 113-123.

GRIŠANOV G. V. \& BELJAKOV V. V. 2000. Nazemnyje pozvonočnyje Kaliningradskoj oblasti. KGU, Kaliningrad.

GRYZ J., KRAUZE D. \& GOSZCZYNSKI J. (in press). The small mammals of Warsaw as based on the analysis of tawny owl Strix aluco pellets. Annales Zoologici Fennici 45.

JęDRZEJEWski W., JĘDRZEJEwska B., ZuB K., RupRECHT A. L. \& BystRowski C. 1994. Resource use by Tawny Owls Strix aluco in relation to rodent fluctuations in Białowieża National Park, Poland. Journal of Avian Biology 25: 308-318.

KOWALSKI K. 1961. Materiały do znajomości fauny ssaków Puszczy Piskiej. Acta Theriologica 4: 295-296.

KOWALSKI M. \& LESINSSI G. 1988. Drobne ssaki w pokarmie puszczyka Strix aluco znad jeziora Luknajno. Chrońmy Przyrodę Ojczystą 4: 80-82.

KRAPP F. 1999. Crocidura leucodon (Hermann, 1780). In: MitCHELl-JONES A. J., AMORI G., BOGDANOWICZ W., KRYŠtuFEK B., REIJNDERS P. J. H., SPITZENBERgER F., STUBBE M. J. B. THISSEN M., VOHRALIK V. \& ZIMA J. (eds), The atlas of European mammals, pp. 64-65. Poyser Natural History, London, 484 pp.

LESIISKI G., BLICHARSKI M. \& SIELECKI M. 1998. Stanowisko smużki Sicista betulina kolo Warszawy. Kulon 3: 101-103.

LUNIAK M. \& NOWICKI W. 1990. Występowanie ssaków w Warszawie. In: ZIMNY H. (ed.), Funkcjonowanie układów ekologicznych w warunkach zurbanizowanych, pp. 230-245. Wydawnictwo SGGW-AR, Warszawa.

MorRIS P. A. 1999. Muscardinus avellanarius (Linnaeus, 1758). In: MITCHELL-JoNES A. J., AMORI G., BOGDANOWICZ W., KRYŠTUFEK B., REIJNDERS P. J. H., SPITZENBERGER F., STUBBE M. J. B., THISSEN M., VOHRALíK V. \& ZIMA J. (eds), The atlas of European mammals, pp. 296-297. Poyser Natural History, London, 484 pp.

OsoJCA G. \& ŻMIHORSKI M. 2004. New locality of common dormouse Muscardinus avellanarius in Romincka Forest (NE Poland). Kulon 9: 129-130.

PUCEK Z. 1983a. Sicista betulina (Pallas, 1778). In: PUCEK Z. \& RACZYŃsKI J. (eds), Atlas rozmieszczenia ssaków w Polsce, pp. 132-134. PWN, Warszawa, 188 pp.

PUCEK Z. 1983b. Muscardinus avellanarius (Linnaeus, 1758). In: PUCEK Z. \& RACZYŃSKI J. (eds), Atlas rozmieszezenia ssaków w Polsce, pp. 137-138. PWN, Warszawa.

PUCEK Z. (ed.) 1984. Klucz do oznaczania ssaków Polski. PWN, Warszawa, 388 pp.

PUCEK Z. 1999. Sicista betulina (Pallas, 1778). In: MitCHELl-JONES A. J., AMORI G., BOGDANOWICZ W., KRYŠTUFEK B., REIJNDERs P. J. H., SPITZEnBERGER F., STUBBE M. J. B. Thissen M., VOHRALIK V. \& ZIMA J. (eds), The atlas of European mammals, pp. 144-145. Poyser Natural History, London, 484 pp.

PUCEK Z. \& MiChalAK I. 1983. Crocidura leucodon (Hermann, 1780). In: PUCEK Z. \& RACZyŃsKi J. (eds), Atlas rozmieszczenia ssaków w Polsce, pp. 60-61. PWN, Warszawa, 188 pp.

PUCEK Z. \& RACZYŃSKI J. (eds) 1983. Atlas rozmieszezenia ssaków w Polsce. PWN, Warszawa, 188 pp.

RACZYNSKK J, FEDYK S., GĘBCZYŃSKA Z. \& PUCEK M. 1984. Distribution of Micromammalia against natural differentiation of the Biebrza Valley habitats. Pol. Ecol. Stud. 10: 425-445.

RuPRECHT A. L. \& SzWAGRZAK A. 1987. Zur Ernährung der Eulen im Westteil des Bialowieza-Urwaldes. Ökologie der Vögel 9: 89-96.

STERZYŃSKA M. \& LESIŃSKi G. 2004. Kręgowce, bezkręgowce. In: BANASZUK H. (ed.), Kotlina Biebrzańska i Biebrzański Park Narodowy. Aktualny stan, walory, zagrożenia i potrzeby czynnej ochrony środowiska, pp. $438-455$. Wydawnictwo Ekonomia i Środowisko, Białystok, $528 \mathrm{pp}$.

TIŠEČKNN A. K. 1997. Comparative food niche analysis of Strix owls in Belarus. In: DUNCAN J. R., JOHNSON D. H. \& NiCHOLLS T. H. (eds), Biology and conservation of owls of the Northern Hemisphere: 2nd Int. Symp., USDA, Forest Service General Technical Report NC-190, pp. 456 460, St. Paul, MN: North Central Forest Experiment Station, Winnipeg, Canada, $635 \mathrm{pp}$.

ŻMIHORSKi M. \& OSoJCA G. 2006. Diet of the Tawny Owl (Strix aluco) in the Romincka Forest (North East Poland). Acta Zoologica Lituanica 16: 54-60. 


\section{STRESZCZENIE}

[Stanowiska trzech rzadkich gatunków ssaków w środkowej i pólnocno-wschodniej Polsce]

Analiza 69 zbiorów zrzutek puszczyka Strix aluco (w tym 28 zawierających powyżej 100 ofiar) wykazala obecność trzech rzadkich gatunków ssaków na Mazowszu i Podlasiu: orzesznicy Muscardinus avellanarius (11 stanowisk), smużki leśnej Sicista betulina (3) i zębielka bialawego Crocidura leucodon (2). Stwierdzone stanowiska uzupelniają dane na temat ich występowania w pobliżu granicy zasięgu i pozwalają na korektę przebiegu tej granicy w przypadku orzesznicy w okolicach Warszawy. Stwierdzono, że niektóre obszary stanowią ważne ostoje tych ssaków: Puszcza Kampinoska - orzesznicy, natomiast Dolina Biebrzy - zarówno orzesznicy, jak i smużki leśnej. 